\title{
Nosocomial Mycobacterium tuberculosis transmission among healthcare students in a high incidence region, in Vitória, State of Espírito Santo
}

\author{
Transmissão nosocomial por Mycobacterium tuberculosis nos estudantes \\ da área de saúde em uma região de alta incidência \\ de tuberculose, Vitória, Estado do Espírito Santo
}

\author{
Ethel Leonor Noia Maciel', Waleska Meireles ${ }^{1}$, Ana Paula Silva ${ }^{1}$, \\ Karina Fiorotti ${ }^{1}$ and Reynaldo Dietze $^{1}$
}

\begin{abstract}
This open comparative study for evaluating hypersensitivity to tuberculin among medical students ( $n=441)$, nursing students ( $n=178)$ and economics students ( $n=230$ ) in Vitória, State of Espirito Santo, had the aim of assessing whether the prevalence of positive tuberculin tests among healthcare students could be used as a sentinel event for nosocomial transmission in localities with high endemicity. There was a significant change in the frequency of purified protein derivative reactivity in the nursing students (20.3\%) and medical students (18.4\%), in comparison with the economics students $(6 \%)(p<0.001)$. As expected, the medical and nursing students had more knowledge about tuberculosis than did the economics students $(p<0.001)$. Our data suggest that the incidence of Mycobacterium tuberculosis infection among nursing and medical students in our region, which has high endemicity of tuberculosis, does not differ from what is found in low-incidence countries. These data reinforce the need for implementing biosafety programs for this target population.
\end{abstract}

Key-words: Students. Tuberculosis. Tuberculin test. Health care students. Nosocomial transmission.

\section{RESUMO}

Este estudo aberto, comparativo, para avaliar a hipersensibilidade a tuberculina em estudantes de medicina ( $n=441)$, enfermagem ( $n=178$ ) e economia (n=230) em Vitória, ES, teve por objetivo avaliar se a prevalência de teste tuberculínico positivo em discentes da área da saúde poderia ser utilizada como evento sentinela de transmissão nosocomial em locais de alta endemicidade. Houve mudança significante na frequiência de reatividade purified protein derivative no grupo de estudantes de enfermagem (20,3\%) e medicina (18,4\%) comparativamente ao grupo dos estudantes de economia (6\%) p<0,001. Como esperado os alunos de medicina e enfermagem tem mais conhecimento sobre a tuberculose que os de economia ( $p<0,001)$. Nossos dados sugerem que a incidência da infecção pelo Mycobacterium tuberculosis em estudantes de enfermagem e medicina na nossa região com alta endemicidade de tuberculose não difere de países com baixa incidência da doença. Estes dados reforçam a necessidade de implementação de programas de biossegurança para essa população-alvo.

Palavras-chaves: Estudantes. Tuberculose. Teste tuberculínico. Estudantes de área de saúde. Transmissão nosocomial.

Tuberculosis (TB), a disease that is caused by Mycobacterium tuberculosis (MTB), is one of the most important causes of mortality in the world, among infectious diseases. Approximately one third of the world's population is infected with MTB. The disease is responsible for about eight million new cases and three million deaths per year ${ }^{12} 15$. In Brazil, 90,000 new cases and more than 5,000 deaths occur every year ${ }^{8}$.
The transmission of Mycobacterium tuberculosis in healthcare facilities is of great concern nowadays. Several outbreaks of nosocomial TB, particularly in North America, accompanied the resurgence of the disease in the general population in the late 1980 s and early $1990 \mathrm{~s}^{5}$. Multiple factors contributed towards this problem, including deterioration of the public health infrastructure, the HIV

\footnotetext{
1. Núcleo de Doenças Infecciosas da Universidade Federal do Espírito Santo, Vitória, ES.

Address to: Dr ${ }^{\mathrm{a}}$ Ethel Leonor Noia Maciel. Núcleo de Doenças Infecciosas/CCS/UFES. Av. Marechal Campos 1468, Maruípe 29040-091 Vitória, ES

e-mail: emaciel@ndi.ufes.br

Recebido em: 24/10/2006

Aceito em: 20/6/2007
} 
epidemic and inadequate infection control measures in healthcare facilities ${ }^{11}$.

In response to this threat, the Centers for Disease Control and Prevention (CDC) published revised guidelines for the prevention of TB transmission in healthcare facilities in 1990, 1994 and $2005^{2}$. In these documents, several recommendations for healthcare settings were made, including guidelines for surveillance and reporting in healthcare facilities that provide care for patients at risk of tuberculosis.

This poses the problem of how and for whom this recommendation should be implemented in a country with high endemicity such as Brazil, where healthcare providers usually work in more than one healthcare facility because of their low salaries. Because of this mobility, it is often difficult to establish the source of infection. Our study was designed to quantify the risk of TB infection among students involved in patient care, and to evaluate their role as alternative sentinel markers for nosocomial transmission.

\section{MATERIAL AND METHODS}

Volunteer selection/data collection. This comparative study was performed from April 1999 to August 2002 and involved students from three different undergraduate courses at the Federal University of Espírito Santo: economics, medical and nursing students. The total registered number of students in these three courses was 913: 460 in the medical school, 223 in the nursing school and 230 in the economics school. Out of this total, 837 agreed to participate in the study: 441 (95.8\%) from the medical school, 178 (79.8\%) from the nursing school and 218 (94.8\%) from the economics school. The volunteer subjects' ages ranged from 18 to 27 years. The medical and nursing students were considered to be groups at high risk of acquiring MTB infection, while the economics students were a low-risk group (reference category).

Tuberculin skin test. The antigen used for the tuberculin skin test (TST) was PPD Rt23 2TU/0.1ml (State Serum Institute, Copenhagen), dispensed by the Brazilian National Tuberculosis Program9. After giving informed consent, the volunteers received an intradermal injection of $0.1 \mathrm{ml}$ of purified protein derivative (PPD) into the dorsal surface of the forearm, applied by a certified nurse. The same nurse was responsible for applying and reading all the TSTs. The positive cutoff point for the TST was $10 \mathrm{~mm}$ of induration in the 72-hour reading. Any subject with a negative reaction to the first TST underwent a second TST after an interval of one to three weeks, in order to rule out the booster phenomenon. The second test reading was recorded as the final result?

Questionnaires. An initial questionnaire was applied to all subjects, with questions regarding professional and community exposure to TB, BCG (Bacillus Calmette-Guérin) vaccination status, previous tuberculosis or TST, immunosuppression and demographic information. A second questionnaire, which was anonymous except for age and study semester, was applied to evaluate the participants' specific knowledge on tuberculosis, including basic facts about disease transmission, clinical symptoms and microbiology, and their level of self-concern regarding professional exposure to TB.

Data analysis. The data were analyzed using STATA 9 (StataCorp LP, College Station, Texas). The statistical significance of levels of association between categorical variables was compared using the Fisher exact test. A confidence internal (CI) of $95 \%$ was used in all odds ratio (OR) calculations.

\section{RESULTS}

Out of the 441 medical students and 218 economics students enrolled, 14 (3.1\%) and 17 (7.7\%) of the subjects, respectively, were not available for PPD measurement in the sequential second application for those who were negative in the first application. The booster effect rate found was insignificant (average of $1 \%$ in the groups studied). All the enrolled students answered the questionnaire. Questionnaire and PPD results were available from 427 medicine students, 201 economics students and 178 nursing students.

The existence of previous BCG vaccination was confirmed by interview and evaluation of the BCG scar and most of the students were found to have been vaccinated. Only $2 \%, 1 \%$ and $2 \%$ of the economics, medical and nursing students respectively were found not to have been vaccinated, and there was no statistically significant difference in these proportions.

Among the medical students, two (0.5\%) students had previously had clinical tuberculosis and had received treatment, and $37(8.6 \%)$ said they had previously undergone a PPD test, with only one being positive. Thirteen (3\%) of the subjects had knowledge of a domestic contact or other intimate contact with TB before their clinical exposure during medical school. Among the nursing students, one had had pulmonary tuberculosis and seven (4\%) said that had had close contact with TB in the family environment. Among the economics students, two (1\%) had previously had tuberculosis treatment and $11(5 \%)$ said they had been in close domestic contact with an active TB case. These differences were not statistically significant.

The medical and nursing students were significantly better informed about tuberculosis than were economics students. The score of correct answers in the questionnaire relating to tuberculosis was $96 \%$ for the medical students, $91 \%$ for the nursing students and $66 \%$ for the economics students. The medical students obtained twelve times more correct answers than did the economics students ( $\mathrm{OR}=12 ; 95 \% \mathrm{CI}: 7.0-20.7 ; \mathrm{p}<0.001)$. The nursing students obtained five times more correct answers than did the economics students ( $\mathrm{OR}=5 ; 95 \%$ CI: 2.9-9.2; $\mathrm{p}<0.001$ ) (Table 1).

Tuberculin skin tests were available from 837 individuals, 72 hours after application of the test, for evaluation of the results. These tests were administered during class hours and were done class by class, which made it possible to reduce the losses during follow-up. The nursing students had a strong PPD reaction in $20.3 \%$ of the cases, whereas this was found among $6 \%$ of the 
Table 1 -Association between correct answers in the questionnaire and university course.

\begin{tabular}{lrrrr}
\hline Variable & number & $\%$ & OR (CI) & p-valor \\
\hline Medicine students & 409 & 96,0 & $12(7-20)$ & 0.0001 \\
Nursing students & 162 & 91,0 & $5(2.9-9)$ & 0.0001 \\
Economics students* & 133 & 66,0 & & \\
\hline
\end{tabular}

*Reference category OR: odds ratio CI: confidence internal

economics students. This difference was statistically significant (OR $=3$; 95\% CI: 2.06-7.73; $\mathrm{p}<0.001)$. The medical students had a strong PPD reaction in $18.4 \%$ of the cases, compared with $6 \%$ of the economy students (OR $=3.5$; $95 \% \mathrm{CI}$ : 1.91-6.38; $\mathrm{p}<0.001$ ) (Table 2).

With regard to the contact at the university with a pulmonary TB patient, 154 (35\%) of the medical students and 75 (42\%) of the nursing students reported a contact, while the economics students just reported home contact. This difference was highly significant $(\mathrm{p}<0.0001)$ (Table 3).

Table 2 - Distribution of PPD results among the students.

\begin{tabular}{|c|c|c|c|c|}
\hline \multirow{2}{*}{$\frac{\text { Variable }}{\text { Medicine students }}$} & \multicolumn{2}{|c|}{$\mathrm{PPD}+$} & \multirow{2}{*}{$\begin{array}{r}\text { OR (CI) } \\
3.5(1.91-6.38)\end{array}$} & \multirow{2}{*}{$\frac{p \text {-valor }}{0.0001}$} \\
\hline & 78 & 18.4 & & \\
\hline Nursing students & 36 & 20.3 & $3(2.06-7.73)$ & 0.0001 \\
\hline Economics students* & 12 & 6.0 & & \\
\hline
\end{tabular}

Table 3 - Distribution of contact with TB cases during university.

\begin{tabular}{lrrrr}
\hline Variable & \multicolumn{2}{c}{ Contact during } & OR (CI) & p-valor \\
& undergraduate course & & \\
\hline Medicine students & 154 & $35 \%$ & $24(7.8-74.82)$ & 0.0001 \\
Nursing students & 75 & $42 \%$ & $28(9-87.9)$ & 0.0001 \\
Economics students* & 133 & $66 \%$ & & \\
\hline
\end{tabular}

* Reference category OR: odds ratio CI: confidence internal

\section{DISCUSSION}

The university hospital studied here is a referral hospital for the State of Espírito Santo for admission of patients with tuberculosis. During the study period, there was an average of 123 hospitalizations/year due to tuberculosis. Among these study volunteers, the prevalence of PPD reactivity was $20.3 \%$ among the nursing students and $18.4 \%$ among the medical students, which was high in comparison with the prevalence among economics students. The risk of infection was about three times greater when there was contact with TB patients during the course. These results reinforce the data in the literature that indicate that health profession students are a high-risk population for acquiring TB infection and emphasize the importance of occupational exposure during professional training 461012 .

The reference to prior BCG vaccination, confirmed by the presence of a vaccine scar, is important for interpreting the results from the PPD test. Studies have demonstrated that individuals vaccinated during childhood and tested after an interval greater than or equal to five years display a tuberculin reactivity pattern similar to the reference population that they are part of ${ }^{7}$.

Contact with bacilliferous patients is the principal risk factor for PPD conversion ${ }^{41214}$. This risk can be aggravated by nonutilization of protective measures, as reported by the students who presented PPD conversion.

Hospitalization of patients in wards with isolation safeguards was an important protective factor against TB, clearly confirming what the U.S. guidelines and, more recently, the Brazilian guidelines have recommended ${ }^{4813}$. However, not all of this university hospital's isolated environments have negative air pressure (37\% of the PPD-negative group reported this resource).

Our data also suggest that the prevalence of TB infection among nursing and medical students in our setting, in a highincidence country, does not differ from that found in Spain, a low-incidence country ${ }^{4}$. This reinforces the need for implementing special biosafety programs targeting this professional group.

\section{REFERENCES}

1. Brudney K, Dobkin J. A tale of two cities: Tuberculosis control in Nicaragua and New York City. Seminars in Respiratory Infections 8:261-272, 1991.

2. Center for Disease Control and Prevention. Guidelines for preventing the transmission of tuberculosis in health care settings with special focus on HIV related issue MMWR 54:1-141, 2005.

3. Diehl HS, Boynton RE, Geist-Black S. Prevention of Tuberculosis among student of medicine. The Journal of the American Medical Association 138: 8-10, 1948.

4. Esteban J, Gadea I, Fernandez-Roblas R, Granizo JJ, Soriano F. Tuberculous infection in student nurses in Madrid, Spain. The International Journal against Tuberculosis and Lung Disease 5:583-584, 2001.

5. Kritski AL Co-infecção M. tuberculosis/HIV. In: Veronesi R, Focaccia R (eds) Tratado de Infectologia. Atheneu, São Paulo, volume 1, p.947-959, 1996.

6. Meade GM. The prevention of primary tuberculous infections in medical students. The American Review of Tuberculosis 58:675-683, 1948.

7. Menzies D. Interpretation of Repeated Tuberculin Tests. Boosting, Conversion, and Reversion. The American Journal of Respiratory Critical Care Medicine 159:15-21, 1948.

8. Ministério da Saúde. Controle da Tuberculose: uma proposta de integração ensino-serviço. Campanha Nacional Contra a Tuberculose/Núcleo de Tecnologia Educacional para a Saúde. $4^{a}$ edição, 1994.

9. Ministério da Saúde. Manual de Normas para o Controle da Tuberculose Centro Nacional de Epidemiologia. Coordenação de Pneumologia Sanitária. 4ª edição, 1995.

10. Myers JA, Boynton RE, Kernan P, Cowan D, Jablon S. Sensitivity to tuberculin among students at the University of Minnesota. The American Review of Tuberculosis 75:442-460, 1957.

11. Sepkowitz KA, Raffalli J, Riley L, Kiehn TE, Armstrong D. Tuberculosis in the AIDS era. Clinical Microbiology Reviews 8:180-199, 1995.

12. Sepkowitz KA, Schluger NW. Tuberculosis and the health care worker. In: Rom WN, Garay S (eds) Tuberculosis Browand Boston, Toronto 77:935-943, 1996.

13. Silva VM, Cunha AJ, Oliveira JR, Figueira MM, Nunes ZB, DeRiemer K, Kritski AL. Medical students at risk of nosocomial transmission of Mycobacterium tuberculosis. The International Journal against Tuberculosis and Lung Disease 4:420-426, 2000.

14. Teixeira L, Maciel E, Dutra ME, Perkins MD, Johnson JL, Valle Dettoni V. Simultaneous comparison of reactivity to purified protein derivative TR-23 and Tubersol in health care workers in Vitória, Brazil. The International Journal against Tuberculosis and Lung Disease 4:1074-1077, 2000.

15. World Health Organization. WHO Report on the Tuberculosis Epidemic, 1995. 